\title{
Strategy-making in a loosely coupled system:
}

\author{
Citation for published version (APA):
}

Foss, N. J., \& Møllgaard, P. (2020). Strategy-making in a loosely coupled system: The guided evolution of the Copenhagen Business School. Beta: Scandinavian Journal of Business Research, 34(1), 68-88. https://doi.org/10.18261/issn.1504-3134-2020-01-04

Document status and date:

Published: 01/01/2020

DOI:

10.18261/issn.1504-3134-2020-01-04

Document Version:

Accepted author manuscript (Peer reviewed / editorial board version)

Document license:

CC BY-NC-ND

\section{Please check the document version of this publication:}

- A submitted manuscript is the version of the article upon submission and before peer-review. There can be important differences between the submitted version and the official published version of record.

People interested in the research are advised to contact the author for the final version of the publication, or visit the DOI to the publisher's website.

- The final author version and the galley proof are versions of the publication after peer review.

- The final published version features the final layout of the paper including the volume, issue and page numbers.

Link to publication

\footnotetext{
General rights rights.

- You may freely distribute the URL identifying the publication in the public portal. please follow below link for the End User Agreement:

www.umlib.nl/taverne-license

Take down policy

If you believe that this document breaches copyright please contact us at:

repository@maastrichtuniversity.nl

providing details and we will investigate your claim.
}

Copyright and moral rights for the publications made accessible in the public portal are retained by the authors and/or other copyright owners and it is a condition of accessing publications that users recognise and abide by the legal requirements associated with these

- Users may download and print one copy of any publication from the public portal for the purpose of private study or research.

- You may not further distribute the material or use it for any profit-making activity or commercial gain

If the publication is distributed under the terms of Article $25 \mathrm{fa}$ of the Dutch Copyright Act, indicated by the "Taverne" license above, 


\title{
STRATEGY-MAKING IN A LOOSELY COUPLED SYSTEM: THE GUIDED EVOLUTION OF THE COPENHAGEN BUSINESS SCHOOL
}

\author{
Nicolai J. Foss \\ Department of Strategy and Innovation \\ Copenhagen Business School \\ Kilevej 14, $2^{\text {nd }}$ fl.2000 Frederiksberg; Denmark \\ Nif.si@cbs.dk \\ Department of Strategy and Leadership \\ Norwegian School of Economics \\ Helleveien 40; 5045 Bergen; Norway \\ Peter Møllgaard \\ Maastricht University School of Business \& Economics \\ Tongersestraat 53, 6211 LM Maastricht, Netherlands \\ h.moellgaard@maastrichtuniversity.nl
}

Acknowledgments We thank (without implicating) Anne Ulstrup Mortensen, Charlotte Aller, Thomas Werner Hansen, Leif Hansen, Tine Büchler Poulsen for assistance, information, and for making various CBS strategy documents available to us. We also thank Finn Junge-Jensen, Niels Blomgren-Hansen, Alan Irwin, Keld Laursen, Peter Lotz, Jan Mouritsen, Bent Petersen, Ingeborg Kleppe, and an anonymous reviewer of this journal for comments on earlier versions of this paper.

\section{Keywords}

University strategy, emergent strategy, organizational ecology 


\title{
STRATEGY-MAKING IN A LOOSELY COUPLED ORGANIZATION: THE GUIDED EVOLUTION OF THE COPENHAGEN BUSINESS SCHOOL
}

\begin{abstract}
While considerable research interest has been devoted to university governance (i.e., the allocation of authority over decisions in a university), little is known about the formation and content of university strategy and how it relates to university governance and organization. To further our knowledge about university strategy and its relation to university governance, we undertake a process study of the emergence of strategies for the organization of research work at one of the largest business schools in the world, the Copenhagen Business School in the period 1987 to 2009. We find that CBS strategy processes in this period followed a "guided evolution" model, in which the top-manager (president) invited bottom-up (research) initiatives, and supported selected ones. Such processes are likely to arise in, and be appropriate for, organizations that are characterized by considerable ambiguity, unclear/vague input/output measures, conflicting interests, and substantial heterogeneity in activities, as exemplified by universitities. We discuss the benefits and costs of the guided evolution approach.
\end{abstract}




\section{INTRODUCTION}

Over the last decades political pressures on universities to become more entrepreneurial, engaged and accountable have steadily accumulated. The attention to university governance and university performance has transgressed the sphere of politics and has become an emerging research topic in a number of social sciences and their intersections (e.g., Shattock, 2003). ${ }^{1}$ However, the connection between university governance and university strategy is a less researched topic (with a few notable exceptions, e.g., Gioia and Chittipeddi, 1991; Gioia and Thomas, 1996; Jarzabkowski, 2002, 2003; Jarzabkowski and Wilson, 2002). This is surprising given that the subjects are clearly linked and are highly topical; for example, transferring decision-making power to university board of directors and staffing these with representatives of "society"-which constitutes a major change of university governance - is often explained and defended in terms of the need to increase the capacity for strategic decision-making at universities (Maassen, 2000).

A classical discussion in strategic management theory concerns the interplay between, and causal order of, "strategy" and "structure" (e.g., Chandler, 1962; Hall and Saias, 1980; Mintzberg, 1994). This discussion informs our treatment of the relation between university strategy and governance. Thus, from the Chandlerian perspective (Chandler, 1962), university governance is chosen by decision-makers at the top to support an already chosen strategy in accordance with the notion that the choice of structure should follow strategy. Here, strategy is an antecedent to the allocation of authority over decisions across the university. In an important corrective to the Chandlerian perspective Mintzberg (e.g., Mintzberg and Waters, 1985) noted that much of strategy emerge in an emergent manner and partly from lower echelons in the organization.

\footnotetext{
${ }^{1}$ By "university governance," we mean the allocation of authority (or "decision rights" or "control," Barzel, 1997) over the use of university resources across a university. This includes, but goes beyond, the is sue of who is represen ted on the board of directors and how they can influence university management. It also includes, for example, the allocation of rights to propose and initiate new teaching, research and dissemination initiatives. For example, in some systems faculty hold many more of such rights than in other systems. University governance also includes the right to select among such initiatives, evaluate and decide on their fate (Fama \& Jensen, 1983), rights that are typically held by university management and/or various decision-making bodies, such as university senates.
} 
Based on a process study (cf. Huy, Corley and Kraatz, 2014) of the Copenhagen Business School (CBS), one of the world's largest business universities, we make a related, yet different point: Universities may benefit from deliberately choosing a mode of governance that fosters the bottom-initiatives that may emerge as a distinct strategy. Thus, causality is reversed relative to the Chandlerian scheme in that structure (i.e., in our context university governance) drives, shapes and gives content to strategies. Our analysis of strategy processes at CBS shows that bottom-up strategy processes can be facilitated by creating an internal environment that provides incentives to start local initiatives (e.g., new research centers) and decentralizes the rights to launch, develop, and manage such initiatives, but keeps the rights to evaluate and make decisions on the continuation or termination of projects in the hands of university leadership (cf. also Foss, 2003). Following Løvas and Ghoshal (2000), we call this approach "guided evolution," and argue that it particularly fits organizations characterized by considerable ambiguity, unclear/vague input/output measures, conflicting interests, substantial heterogeneity in activities, and other characteristics of loosely coupled organizations. Universities have long been argued to possess exactly these characteristics (e.g., Weick, 1976).

The relevance of our findings is that bottom-up strategic processes of the kind we discern at the CBS may be crucial to fostering the entrepreneurial stance and the ability to adapt to a changing environment that a number of writers have claimed to increasingly be necessities for the highperforming, "entrepreneurial universities" with strong ties to stakeholders groups, such as the business community (Clark, 1998; Etzkowitz, 1998, 2003; Rothaermel et al., 2007; Siegel et al, 2007; Styhre and Lind, 2009). Because relevant knowledge that may underpin entrepreneurial initiative and support adaptation to stakeholder demands is often located at lower levels in the university (e.g., with faculty in a specific department), a mechanism has to be constructed that utilizes such knowledge. In principle, this can be done by communicating the knowledge to 
university leadership which makes use of it in strategic decision-making. However, this is often cumbersome and slow, and knowledge may get lost or distorted in the process. Given this, letting entrepreneurial initiative and adaptation reside at lower levels may be the better alternative. While this appears to be understood in the literature on entrepreneurial processes in a university context (e.g., Etzkowitz, 1998, 2003; Siegel et al., 2007), this literature says less about how entrepreneurial bottom-up processes can be called forth, what is an optimal amount of decentralized initiative, and how the balance between the core disciplines of a university and decentralized initiatives can be maintained.

Accordingly, our research question is the following: How can a strategy process in a modern university be organized and governed such that it contributes to making the university entrepreneurial and adaptive and thus contributes to successful long-term performance? Because so little is known about this, we adopt a case-study approach, emphasizing thick description (Geertz, 1973), to help us achieve preliminary answers to our research question. More precisely, our research design may be characterized as a single-case holistic design in that it deals with multiple aspects of a single organization (over time). We specifically examine the evolution of a research strategy at one of the world's largest business schools, namely the CBS. ${ }^{2}$ Our focus is on the period of 1987 to 2009 . We chose this period for our process study as it is a period of unprecedented growth of the school. The period also coincides with the presidency of Finn Junge-Jensen, the longest serving president in the history of the CBS - and the architect of the CBS guided evolution approach. Our interpretation and analysis of the relevant archival sources as well as interviews with key decision-makers in the relevant period makes it credible that in fact Junge-Jensen's particular approach to strategy-making was an independent driver of the growth of the School in the period.

\footnotetext{
${ }^{2}$ Our focus on research, rather than teaching or other business schoolactivities, is motivated by the fact that there is no university without research, and that ultimately research is the key "value driver" in a university. Teaching, knowledge dissemination, funding and the reputation of the university are heavily dependent on the quality of the research activities, and the opposite is true to a smaller extent.
} 
Our findings also points to various challenges and potential pitfalls of a steered evolution approach to university strategy making. Thus, in terms of research methods, ours is a case that is critical (i.e., it puts existing theory (on steered evolution) to a test), typical (i.e., it deals with a relatively typical case, namely a big European business school), and revelatory (i.e., it provides access to a situation not made accessible in previous research) (cf. Yin, 2003: 39-48).

\section{BACKGROUND: UNDERSTANDING UNIVERSITY STRATEGIES}

\section{Context: The Emergence of University Strategy}

The organization and governance of universities has long been the subject of a small literature that treats the university as a distinct organizational form (notably because of the tenure system). ${ }^{3}$ In contrast, the notion that universities engage in strategy-making is a rather recent one. Thus, the notions that universities are de facto engaged in competition with other universities for students, faculty, wealthy private benefactors, reputation, public funds, and general status; that such competition leads to differential performance across universities; and that universities can strategically allocate resources to teaching, research, and knowledge dissemination activities in order to influence the competitive game in their favor are rather recent ones. In contrast, the traditional European, state-financed university of only a few decades back often enjoyed a regional or even national monopoly, and by virtue of this position and its access to the long purse of the tax payers, had to care rather little for the kind of strategic planning that is more pressing to a private university that operates in a more explicit market setting, such as a US non-state university.

Moreover, at least in Europe, universities have been subject to considerable public regulation and powerful trade unions or professional associations that have constrained the room for maneuvre anyway. Shattock (2002: 1) notes that in the case of UK in the period from 1945 to 1980, the

\footnotetext{
${ }^{3}$ Specific institutional features of university organization - in particular, the tenure systemor the democratic nature of traditional university governance - have long captured academic interest, notably from organizational economists (Brown, 2001; Aghion et al., 2009) and political scientists (McConnell and Mortimer, 1971). However, such work typically takes the traditional university model as given, and does not examine and compare alternative organizational designs.
} 
authorities "... worked on the principle that universities were equal or, if not actually equal, should for the most part be treated as such." If players are equal, or at least are treated as such by authorities and politicians, there is little room for strategic management (Barney, 1991). In turn, this promotes an approach to university planning where the emphasis is on distributing resources on staff and facilities to match student numbers, all taking place within a budget constraint defined by government and carried out by means of a "Weberian attachment to regulation and hierarchy and a reliance on an elaborate committee structure" (Shattock, 2002: 25; see also Temple and Whitchurch, 1989).

A number of strong forces have changed this. Internationalization impacts the market for tertiary education, so that universities compete for students and faculty. Governments increasingly fund universities on the basis of performance indicators (Jarzabkowski, 2002). Student choices are to some extent influenced by university rankings. Some rankings only pertain to research performance, but research performance is generally an important component of all rankings. It is an increasingly widespread belief among policy-makers that the taxpaying public needs to be convinced of the soundness of the research undertaken by means of its money, so knowledge dissemination is increasingly stressed as an important part of the mission of a university (Zemsky, Wegner \& Massy, 2005). Broader "research policy," sometimes representing "national priorities," increasingly determine overall resource allocation decisions (Bozeman, 2000). External funding streams become more and more important, and many countries introduce targets for their universities' external funding.

\section{Research on University Strategy}

In terms of research performance, many of these changes are captured by the notion of "Mode II" (Gibbons et al., 1994) - that is, the claim that research is shifting towards a model that is problem-driven, contextual and explicitly inter-disciplinary. One can debate the descriptive 
accuracy of this claim, but it seems hard to deny that it does capture a number of current tendencies that significantly impact the universities. ${ }^{4}$ Similarly, there has been surprisingly little attention to how these changes affect the formation and content of university strategies. ${ }^{5}$

More broadly, the research literature on university strategy is surprisingly small (e.g., Clark, 1998; Shattock, 2003: Chpt. 2). In management research, particularly noteworthy contributions have been made by Dennis Gioia (Gioia and Chittipeddi, 1991; Gioia and Thomas, 1996) and Paula Jarzabkowski (e.g., Jarzabkowski, 2003; Jarzabkowski and Wilson, 2002). ${ }^{6}$ Gioia and Chittipeddi (1991) and Gioia and Thomas (1996) address the sense-making role of the President/CEO, and are only secondarily taken up with the more formal aspects of university organization. Writing from a strategy practice perspective and basing her research on case studies of three UK universities, Jarzabkowski is particularly taken up with studying how resource allocation models are deployed as instruments of control in universities, and the role of the university top-management team in negotiating and enforcing resource allocation across the university in interaction with university committees and departments (Jarzabkowski and Wilson, 2002). A noteworthy aspect of her concern with resource allocation models is that it allows her to characterize the degree of centralization in a university in terms how tight is the control of top management over resource allocation. However, her research does not include the possibility that university top management can choose its resource allocation model in order to stimulate and steer emergent processes in the form of new research initiatives - a case that we document in this research.

\footnotetext{
${ }^{4}$ Some interest has centered on the organizational implications of the Mode II model, mainly in the context of organizing collaboration between universities and industry (Rothaermel et al., 2007). However, very few contributions examine the implications in terms of the internal organization of universities of the above changes (but see Styhre \& Lind, 2009).

${ }^{5}$ As Rothaermel et al. (2007) pointed out, not a single paper has appeared in the top management journal (the Academy of Management Journal) or the top journal in strategy (the Strategic Management Journal), exploring the management, organizational or strategic changes that the change from a Mode I to a Mode II model of knowledge production entails. A keyword based search on Scopus and Google Scholar with combinations of words like "Mode I," "Mode II," "university strategy," and "university governance" sugges ts that their 2007 finding still holds.

${ }^{6}$ Another literature considers university leadership, linking the skill sets of key employees and overall university performance. For example, Goodall (2009) argues that top universities are (and indeed should be) led by top scholars.
} 


\section{Planned and Emergent Strategies}

A key debate in the four decades of existence of strategic management as an academic field concerns the extent to which strategies can be rationally planned and implemented in a top-down manner (cf. Mintzberg, 1994). The case for emergent strategies is often made by pointing to successful historical episodes of strategy emergence, such as the famed transformation of Intel's core business are from memory chips to processors, apparently resulting from a large number of resource allocation decisions undertaken by middle-managers (Burgelman, 1994). Such episodes suggest that individuals placed at lower levels in an organization often possess local knowledge that is superior to that of top management (Hayek, 1945; Jensen \& Meckling, 1992). As is may be too costly to elicit this knowledge from the lower levels in the organization and transfer it to a center so that it can feed into an overall strategic plan, it may make sense to delegate initiative to those lower organizational levels. However, delegating initiative and resource control may result in a de facto delegation of strategic initiative.

Although no systematic contingency model exists on this, it may be broadly hypothesized that the tendency of strategic initiatives to be taken at lower levels of the organization depends on the heterogeneity of (technological, scientific) disciplines that an organization need to control in-house; the extent to which it is reliant on specialist work; the nature of its interdependencies (Thompson, 1967; Weick, 1976); the extent to which it needs to keep permeable boundaries relative to external stakeholders (Whitley, 2006); and the extent to which it is frequently hit by more or less random events to which rapid adaptation is important (Sporn, 1999). In other words, a set of contingency variables plausibly affect the proportion of (top-down) planned and (bottom-up) emergent features of strategies in organizations. Most of these variables seem relevant to universities and the environments in which they operate. A metaphor that has often been applied to characterize 
organizations that operate under conditions similar to the above is that of "loosely coupled systems."

\section{Universities as Loosely Coupled Systems}

Weick (1976) argued that educational organizations, notably universities, do not have strong "technological cores" (i.e., strong technological interdependencies) or strong authority systems that hold the organization together. Rather, they are inherently "loosely coupled systems," implying that organizational units (e.g., departments or research centers) “... are somehow detached, but that each retains some identity and separateness and that their attachment may be circumscribed, infrequent, weak in its mutual effects, unimportant, and/or slow to respond" (Weick, 1976: 3) (see also Orton \& Weick, 1990). ${ }^{7}$ Weick did not pay much attention to the deeper reasons why universities seem to consistently exhibit the quality of being loosely coupled systems, perhaps because the reasons are fairly obvious. Business schools, and more broadly, universities, have multiple disciplines and fields in-house. These are often placed within self-contained departments that typically have responsibilities for their own teaching programs, and interdependencies in research tasks are very small across departments (while interdependencies may exist within departments) (Clark, 1983). ${ }^{8}$ Information asymmetries between top management and faculty are therefore likely to be pronounced, even if management is recruited from among faculty. Inputs and outputs are inherently difficult to measure, and criteria for assessing and rewarding performance are not only difficult to establish and apply, but typically also contested. University faculty members may not be the most docile employees, and faculty that hold strong Humboldtian university ideals may be instinctively

\footnotetext{
${ }^{7}$ While the imagery of a loosely coupled systemmay adequately describe the research side of universities, the teaching side is usually considerably more tightly coupled.

${ }^{8}$ Proponents of the Mode II notion as serts that boundaries between disciplines are breaking down, and that much of the action in terms of future scientific advance is going to emerge from zones of overlap and the new combinations of knowledge that they yield, particularly when these are activated in the context of concrete problem-solving with business (Gibbons et al., 1994). This may prompt new kinds of interdependencies within the university as well as between the university and various external parties, calling for new organizational forms and management approaches to handle such new interdependencies.
} 
hostile to notions that their efforts can and perhaps should be influenced, even "managed," to fit into a larger picture, that is, overall university strategy. Add to this that authority over decision domains have typically been dispersed and sometimes also highly unclear/ill-defined (Barzel, 1997). Managers - usually at the level of department heads, often at the level of deans, and sometimes even at the level of university presidents/rectors-have typically been elected by their peers which may tend to dilute decision rights through an opaque web of rent seekers. This not only creates distinct challenges for the daily management of university, but also for their strategic management. ${ }^{9}$

As argued above the composition of planned and emergent features in strategies is likely to reflect the extent to which the organization conforms to the imagery of a loosely coupled system. If interdependencies are relatively few, infrequent, and not very strong, the need for a detailed coordination of functions, activities and tasks through a strategic plan that accounts for the impact of various contingencies does not seem pressing. The few existing coordination needs can be met in a low-cost manner by means of broad routines and communication within and across units.

Obviously, key strategic decisions remain—such as making overall resource allocation decisions (Jarzabkowski, 2002), defining overall direction, and deciding on practices related to the management of the university's human resources initiating - that cannot be left to decentralized initiative but has to be addressed by top-management. Moreover, top-management can play an active role with respect to stimulating bottom-up initiatives. In other words, in contrast to the tenor of work on "emergent" strategies (Mintzberg and Waters, 1985; Burgelman, 1994; Mintzberg,

\footnotetext{
${ }^{9}$ Some of the above characteristics, and the consequent challenges, may have been accentuated by the move to the "entrepreneurial university" which "... integrates economic development into the university as an academic function along with teaching and research" (Etzkowitz, 1998: 833). Universities are increasingly called upon to bridge the science-industry interface which calls for "entrepreneurial professors" (Lam, 2007) with considerable discretion and the mandate to engage in extramural co-creation with industry partners. Styhre and Lind (2009) argue that the emerging entrepreneurial university requires a "soft bureaucracy" form which retains certain key characteristics of traditional bureaucratic organizations (notably a functional and hierarchical organizational logic) but adds considerable flexibility and decentralization/delegation of decision power, and has looser and more adaptable operating procedures.
} 
1994), decentralized strategic do not necessarily take place unknown to and unintended by topmanagement. On the contrary, organizations may pursue a "guided evolution" approach (Lovas \& Ghoshal, 2000; Foss, 2003) in which emergent strategies do not emerge as a reaction to inflexible top-level strategies (cf. Burgelman, 1994), but are rather stimulated by management in attempt to create variety-generating processes at lower levels of the organization. In other words, how can management best organize the strategy process? In the following we address this research question in a university context, focusing on the case of the Copenhagen Business School.

\section{GUIDED EVOLUTION AT THE COPENHAGEN BUSINESS SCHOOL}

\section{Method and Data Sources}

The aim of the present research is to undertake a detailed study of an extended historical episode, namely the interplay between university governance and research strategy processes at the CBS over somewhat more than two decades (i.e., 1987 to 2009). We triangulate the process data supplied by archival material, secondary sources and interviews to to cast light over the functioning of a guided evolution approach in a university setting (cf. Langley, 1999). As we tell the story of CBS strategy processes in the following, we draw on a priori theory on the mechanisms that may be operative in driving the events described in the relevant written material or described by interviewees. Specifically, it is informed by strategy process research (e.g., Woolridge and Floyd, 1990; Pettigrew, 1992; Lovas and Ghoshal, 2000), but we also rely on ideas from organizational theory (e.g., Jensen and Meckling, 1992; Foss, 2003). These theories partly help to organize data collection and interpretation, and partly serve as something with which the data metaphorically enter into a dialogue (Bansal, Smith, \& Vaara, 2018). This implies that not only are the empirical findings gathered, presented and "colored" by the above theories, but we also want to discuss implications for existing theory of the data. 
Data were mainly gathered through archival sources. ${ }^{10}$ Thus, we gathered and carefully read the key strategy documents from the relevant period, namely Dean of the Economics Faculty (1986), Strategiudvalget (1989) (i.e., the "Strategy Committee"), Stolt (1993), Balslev (1994), Handelshøjskolen i København (1990, 1995), Junge-Jensen (1993, 1995, 2006), and Davies (2008). ${ }^{11}$ These were analyzed using a simple color coding system that indicated key terms of relevance to our research question, and where the relevant terms were indicators of higher level constructs (e.g., "new research initiatives," "new teaching initiatives", "criteria for selecting among initiatives" and so one). We also used color marking to identify key events and their chronology (cf. Langley, 1999).

We also made use of secondary sources, notably books and journal articles about the history of CBS (i.e., Vibæk and Kobbernagel, 1980; Lange, 1992; Foss, 2007; Jacobsen and Sørensen, 2017), a movie that was made for the 2017 centenary, ${ }^{12}$ as well as newspaper articles. For the latter, we used the database Infomedia to conduct a keyword-based search (using combined search items such as (the Danish equivalents to) "strategy", “CBS", "new initiatives," "new study program", "research initiative", etc.). This resulted in the identification of about a dozen relevant newspapers articles. This material was compared to the content of the CBS strategy reports.

Finally, based on the knowledge gathered from the above sources, we conducted interviews (in 2012 and 2013) with former President Finn Junge-Jensen, a former dean, three department heads, a colleague who was hired at the beginning of the relevant period and a colleague who has hired at the end of the period, and two centrally placed administrative officers who had been

\footnotetext{
${ }^{10}$ In the interest of full disclosure we note that both authors were professors at the CBS when the data were collected and served as department heads in parts of the relevant period. On the one hand, this implies that we are indeed "grounded in the organization's culture" (Gioia and Chittipeddi, 1991: 435); on the other hand, it also means that bias is likely unavoidable (i.e., uncritically accepting some socially constructed meanings).

11 These documents were obtained from a university administrator who served as key advisor in the relevant period and who assured us that the above documents were the relevant "official" CBS strategy documents for this period.

12 The movie can be found at: https://vimeo.com/242044567
} 
centrally involved in supporting the various committees that had been tasked with writing reports on past and future CBS strategy. All interviewees, nine in total, were interviewed only once, but made subsequent comments on our written presentation of findings and interpretations based on the interviews.

The three sets of data sources were used to build narratives of strategy processes at CBS, starting with the accounts of overall CBS history in sources such as Vibæk and Kobbernagel (1980) and Lange (2002), and comparing these accounts with the archival material as it concerned major events in the strategizing of CBS. The archival methods provided much detail and prompted the first glimpse of the guided evolution approach. Our emerging narrative of this approach received support from the data obtained through the interviews with our nine informants.

In the following, we present our findings based on the above three sets of data sources.

\section{Historical Background}

Copenhagen Business School was founded in 1917 (as "Handelshøjskolen") by The Danish Society for the Advancement of Business Education and Research ("Foreningen for Unge Handelsmænds Uddannelse")—an industry-based foundation dedicated to providing business education-, which very strongly dominated the first many decades of the School. ${ }^{13}$ In the first decades, teaching centered on basic economics, accounting, basic techniques of commerce-as well as Danish literature! Approximately 100 students were enrolled in the first years of the existence of the school, growing to around 500 at the end of the 1920 s, 850 in the mid-1930s, and about 1,400 at the end of the decade.

The first two professors that were comparable in terms of qualifications, responsibilities etc. to university professors become appointed in 1936 (Julius Hirsch in "commercial science") and in 1937 (Max Kjær-Hansen in managerial economics). Arguably, this marks the beginning of

\footnotetext{
13 The history of the CBS from 1917 to 1980 is told in Vibæk and Kobbernagel (1980), partly in Lange (1992), and in particular in Jacobsen and Sørensen's (2017) massive "corporate history." This subsection relies on these three sources.
} 
Copenhagen Business School as a university. The School followed a steady growth trajectory in the post-war period, continuously expanding in terms of faculty and student mass. In 1965, escalating dependency on state funds led to a change in the regulation of the School, so that it essentially became regulated like the other (state-owned or controlled universities), and a de facto takeover by the Danish state. The end of the 1960s marks a heavy expansion into modern languages. The student body now numbers about 6,500 and the number of faculty about 150 (plus hundreds of external lecturers). The 1970 s and 1980s are characterized by continuous growth and the continuous emergence of new departments and centers (as well as the occasional closing down of existing departments and centers) driven to a large extent by break-outs and spin-offs from existing departments rooted in personal animosities, and with highly non-standard names (at least for a more conventional business school), such as "Center for Cross-Disciplinary Studies" or the "Center for Research in Education.”

\section{A Diverse Business University; Not a Business School}

In the beginning the CBS faculty composition and the subjects they taught were wholly driven by the needs of the local business community (Vibæk \& Kobbernagel, 1980). Over the almost one hundred years of evolution of the CBS there has never been any attempt to imitate the functionally specialized business school that began to take shape in the US towards the Second World War and became dominant in the decades after the War. ${ }^{14}$

To be sure, departments of marketing, organization and finance emerged, but so did departments of foreign trade and tourism. In the post-war period, colorful personalities like Z.D. Lando and Arne Rasmussen were provided the discretion to act as academic entrepreneurs, forming new departments, and developing and offering new courses and programs (Lange, 1992). In a historical perspective, the key characteristics of the current CBS culture-namely, a non-standard

\footnotetext{
${ }^{14}$ As a reflection of this the upstart of an MBA program at CBS is a relatively recent undertaking (1992).
} 
approach to what it means to be a business school, a high degree of tolerance for local entrepreneurship inside CBS, and an explicit embrace of the resulting diversity — are thus not recent innovations, but characteristics that are deeply rooted in the historical legacy of the CBS (Lange, 1992).

Relatedly, CBS has explicitly refrained from adopting or imitating the standard US business school functional-fields-model. Rather, the overall ambition has been to become a university specialized in social science as it applies to business or management. While this may have at some point been an ex post rationalization of the diversity of the CBS in terms of disciplines and fields, during President Finn Junge-Jensen's presidency (1987 - 2009), it increasingly became the official CBS mission. Notably, "business" and "management" are understood in a very broad sense, and representatives of disciplines (e.g., philosophy, anthropology, even theology) that are not usually characteristic of a business school have been included in the disciplinary portfolio of CBS. This diversity is argued to be a source of competitive advantage and a key driver of CBS' differentiation strategy (Jacobsen \& Sørensen, 2017). This diversity is perhaps most clearly reflected in degree programs such as "Business Administration and Sociology", "Business, Language and Culture", "Business Administration and Philosophy", "Business Administration and Psychology" and "Computational Linguistics," and "Business Administration and Psychology". These "combination programs" began in the mid-1980s, were created by bottom-up initiative, and are seen as justified because they meet hitherto unmet needs in the market for tertiary education.

On the research side, too, $\mathrm{CBS}$ ' structure of departments and research units clearly defies the logic of ordinary business schools. Consider, for example the names of three of five largest CBS departments: "Management, Politics and Philosophy," "Intercultural Communication and Management", "Business and Politics."15 The growth of these units has been a matter of

\footnotetext{
${ }^{15}$ The "Business and Politics" department was dissolved in 2018 and faculty placed in otherdepartments.
} 
decentralized initiatives of groups of researchers rather than of deliberate planning on the part of top management. Overall, CBS' historical development has very much been driven by emergent, bottom-up initiatives. However, top management has strongly influenced these processes at critical junctures. It has issued calls for various initiatives, picking among the proposed ones, and, in particular, establishing an institutional framework for the creation of variety in research initiatives and the selection among this variety, in other words, a "guided evolution" approach.

\section{Approaching Research Strategy at CBS}

The first systematic attempts at engaging in a strategy process at the CBS date back to the mid-1980s, specifically to a comprehensive report on "Long Run Planning of Research Areas" by the Dean of the Economic Faculty (1986). The report describes a business school with a faculty size of 143 professors (on the three usual levels) plus 705 (part-time) teaching assistants and external lecturers, and an administration of 58 full-time equivalents serving a population of 10,278 students. ${ }^{16}$ Thus, the ratio of students to permanent staff was $10278 / 143=72$ and it had been increasing dramatically in the first half of the 1980s. This was perceived as a "professional trap" since the situation was only sustainable through increasing class sizes and other rationalization initiatives, as well as deterioration of working conditions for members of the faculty. This meant that the main challenges were retention and recruitment of scientific personnel and a strain on research and teaching infrastructure, notably buildings. Clearly, then, the perceived need to engage in strategic planning was driven by changes in key environmental contingencies.

The structural initiatives suggested by the Dean were to close down two departments (i.e., "Insurance" and "Media Research"), to create three new departments (i.e., "Informatics and Financial Controlling", "Computer and System Sciences," and "Research on Business and Society"), and suggest that the two (!) existing law departments should engage in more coordinated

\footnotetext{
${ }^{16}$ In 2013, the equivalent numbers are: a scientific staff of around 550, roughly 1000 part-time teachers, an administration of 500 and approximately 19,000 students.
} 
research and teaching efforts. In terms of research development, the report suggested that research on internationalization should be of increasing importance in the light of the increasing internationalization of the business world and the initiated internationalization of CBS teaching programs. Other research areas that were identified as potentially important were public-private partnerships; law \& economics; management, control and innovation; communication; computer and systems sciences; operations research; and logistics. In an interesting ancitipation of Mode II thinking, each one of these areas was supposed to be organized across established departments, although the newly established departments were supposed to be the anchor of a few of them.

In 1989, President Finn Junge-Jensen organized a Strategic Committee (1989) (in which he himself served) that developed a series of new suggestions including a new research profile within Management of Technology, the development of an MBA program, and the establishment of a center for post-experience curriculum. Most of these initiatives were implemented through the 1990s. In 1990, the CBS organized another round of strategic development and decided that internationalization was the name of the game.

\section{Formalized Strategic Planning}

During 1993-1994, President Junge-Jensen decided to implement a more formalized strategic approach. Calling for increased awareness of strategic issues at all levels, he (Junge-Jensen, 1993: 2) emphasized that

[i]n the organization of the strategic process, a strong commitment from decentral players (study boards and departments) as well as centralized strategic considerations have to be ensured. ... It is the role of top management to structure this dialogue through the presentation of views regarding the central issues. 
The main issues identified included the establishment of performance measures at all levels, increased international quality in research, and introduction of systematic, regular research assessments.

The 1993-1994 strategic planning exercise resulted in a report that was discussed at a two-day strategy conference in August 1994 with eighty participants, including external stakeholders. One of the topics that were discussed at length was how or whether it would be possible to proactively prioritize among research areas to further the strategic aims of the CBS. The solution to this was to not make upfront decisions on this, but rather to rely on an explicitly experimental process (Balslev, 1994). Junge-Jensen (1995) summarized the result of the strategic development and coined five principles that are still influential even today; thus, CBS should 1) have an "international profile with a national anchoring"; 2) be broader in scope than a traditional US type business school; 3) be innovative in terms of pedagogical principles; 4) be a networking organization with strong links to the business community, as well as to academic institutions at home and abroad; and 5) be a "learning university" combining the classical notion of a university with the modern notion of the learning organization.

In "Strategic Status" published (in Danish) in 1998, CBS made an account of "established positions of strength" which are identified by four characteristics: 1) three or more researchers operate in the research area, which 2) has a considerable, internationally recognized scientific production, and 3) has received external funding; and 4) has organized workshops, $\mathrm{PhD}$ courses, or the like. "Potential positions of strength" were similarly identified by 1) three or more researchers operating in the research area; 2) established inter-departmental or cross-institutional research networks; 3) collaboration around existing research centers or on common projects; and 4) considerable scientific publication in refereed outlets. The report identified eight established and nine potential positions of strength and decided to "prioritize" three new applied research programs, 
one cross-institutional research collaboration and twelve research areas within the established departments.

It took seven years and numerous strategy discussions at various fora at the CBS (i.e., faculty councils, academic councils, groups involving heads of department and study program directors) before "Strategy 2010" appeared in late 2005 (see Junge-Jensen, 2006). This strategy built on "Strategic Status 1998" as well as the performance agreement for 2000-2003 that CBS had entered into with the Danish Ministry of Science, Technology and Innovation. ${ }^{17}$ The three strategic focus areas - namely, "internationalization with a local anchoring," "intensified partnership with the business community," and "the learning university" were kept and even more emphasis was placed on these. In addition, Strategy 2010 focused on four different research areas as deserving attention: 1) innovation, entrepreneurship and leadership; 2) the experience economy (creative industries research); 3) business and politics; and 4) cultural and area studies. This was a very clear example of an attempt at strategy process induced from the top.

\section{Groping in the Dark?}

The strategy documents of the Copenhagen Business School in the period we studied often do not go significantly beyond statements of mission and vision that are based on rather fragmentary analyses of external and internal conditions (typically generated through departmental selfassessments and statements of future needs and ambitions). Concrete actions are decided upon (cf. above), but these are typically rather isolated ones that only impacts one or a few departments and the specifics of their implementation are not discussed (e.g., Junge-Jensen, 2008: 1). Thus, although it is clearly the case that strategic planning gets more ambitious, detailed and confident towards the end of the period, the strategy documents are usually very vague with respect to the actual content of strategies, the processes that will build such content, the organizational design that can support

\footnotetext{
${ }^{17}$ From around 2000 the Ministry of Science, Technology and Innovation started governing universities in Denmark through a series of consecutive three-years contracts.
} 
these processes, and the criteria used to evaluate performance under any particular strategy. Similarly, the implications in terms of the resource commitments that will have to be made to realize the strategy are often not dealt with at all.

From one perspective, this reflects an organization and leadership with little strategy-making experience, groping towards the definition of goals, and the activities and resource commitments implied by the goals (a characterization that probably fits most other European universities in the relevant period). However, from a different perspective, formalized, detailed, top-down strategy processes were alien to the historical legacy of CBS being driven almost from the inception of the school by bottom-up initiatives (Lange, 1982; Jacobsen and Sørensen, 2017). Thus, when CBS began employing more a systematic strategy process - as reflected in the years of organization-wide work that resulted in "Strategy 2010" (Junge-Jensen, 2006)—, the outcome was a distinct overall approach to strategy making that reflected CBS' history of bottom-up initiative.

\section{Interpreting the Findings: CBS Strategy as Guided Evolution}

CBS' strategic approach within the research domain may be described as one of guided evolution (Løvas and Ghoshal, 2000; Foss, 2003). In this conceptualization, an organization is seen as an ecology that is at least partly designed to produce strategic initiatives and select among those initiatives in a manner that maximizes the organization's overall objective function. The basic idea is explained by organizational theorist (and CBS honorary doctor!) James March (1994: 45):

The idea is not that any imaginable organization can be designed and built but that natural developmental processes ... can be affected significantly by relatively small, timely interventions. The engineering of evolution involves understanding those processes well enough to intervene in history and produce organizational effects.

In this evolutionary perspective, the units of selection are strategic initiatives; variation increases when new strategic initiatives are put forward; and the agents of selection and retention are in 
principle everyone who participates in the strategy process (Løvas and Ghoshal, 2000: 876). However, top-management plays a critical by intervening at critical junctures and by defining the overall framework within which strategic initiatives emerge and are selected. Specifically, the guided evolution perspective differs from these related notions by stressing that management deliberately call forth new strategic initiatives from lower echelons in the organization, select a number of these upfront, based on (typically) broad and soft criteria and then perform a later selection of initiatives that, having demonstrated their viability, are allowed to continue on a more permanent basis. In the following we discuss some of the specific mechanisms of the guided evolution approach as it played out in the context of the Copenhagen Business School.

Signaling. Engaging in signaling is a communicative and symbolic act (Gioia and Chittipeddi, 1991). Signals transfer information across individuals and serve to focus attention. Specifically, leaders may signal to followers in order to induce certain behaviors that followers (rationally) choose because they trust that the leader possesses superior information (Hermalin, 1998). Most of our interviewees highlighted a very important act of signaling performed by JungeJensen in the mid-1990s, namely what was what came to be known in CBS lore as the "pastoral letter." This was a circular on research performance directed to all scientific staff at CBS in which Junge-Jensen clarified the performance expectation in the research dimension; specifically, faculty was obliged to deliver least one item per year. An "item" could be anything from a working paper over a book to an article in a refereed international journal. In the context of current academic environments, this may sound like miniscule productivity requirements, but at the time it was a powerful, symbolic change that was widely discussed, and seen as quite controversial.

Seeding local initiatives. Towards the end of the 1990s, Junge-Jensen initiated the arguably most important bottom-up initiative of his presidency, namely the establishment of an increasing number of research centers. They were supported with seed money, typically close to two hundred 
thousand Euros over a three years period. Virtually all of the research centers were financed with seed money by a fund ("Ledelsespuljen") that was under the full discretionary control of the President. The fund was explicitly designed by Junge-Jensen as a central R\&D fund that could rapidly and efficiently support worthwhile strategic initiatives from lower levels of the CBS organization. It was financed by effectively "taxing" the income produced by the CBS study programmes with a small percentage on an annual basis. In other words, the fund was a semipermanent one, amounting to (in 2009) approximately 4.5 million Euros.

The initiative for a new center typically was a bottom-up process, prompted by JungeJensen's explicit policy of considering all serious proposals (and in actuality, approving a large percentage of these) on an ad hoc basis. The criteria that were applied to assess proposals had to do with the personal commitment of the proposer to the proposed project; the consistency of the project with overall CBS strategy; and the importance to CBS of the proposed center (interview with Finn Junge-Jensen, June 2012). In addition, proposals would involve a number of faculty members (typically, minimum 2-3 full professors), detail close relations to relevant external stakeholders, and contain a relatively detailed plan for activities over a three years horizon.

Establishing research centers within departments is, of course, nothing new, and in many universities such centers serve as semi-formal structures that coordinate teaching and research efforts. However, in Junge-Jensen's thinking, centers were ways of improving motivation by granting autonomy over a budget, mobilizing local entrepreneurial initiative, making closer contacts to business, and otherwise signaling increased engagement within an area to the external environment. Indeed, a number of centers were organized outside of the existing departments, effectively becoming new departments. The strong emphasis on the center, rather than the department, as the locus of new entrepreneurial initiative arguably reflects Junge-Jensen's 
conviction that "what really counts in terms of impact is the individual scholar and the university, not departments as such."18

Centers served numerous purposes in terms of strengthening individual incentives and economizing with information within the CBS hierarchy. Overall, the centers supplied bottom-up initiatives that made CBS' strategy concrete in terms of actual research efforts (and new, derived teaching efforts). Centers functioned as relatively inexpensive motivational instruments as center leaders and members would be motivated by the prospect of assuming responsibility in a more visible structure for their favorite research projects, a purpose explicitly envisioned by JungeJensen. By creating incentives for entrepreneurial initiatives within selected-ostensibly frontierareas, they contributed to CBS' organizational learning. The emphasis on the bottom-up approach helped to economize with top-management information and attention: In a guided evolution approach, top-management does not apriori identify who shall receive additional funding of research activities. Rather, the bottom-up process and the rules guiding the process establish a competition for such funding, and the task of top-management is to select among competitive proposals. ${ }^{19}$ Finally, centers served as vehicles of stimulating more inter-disciplinary and inter-field research; thus, it was required that members of a research center must come from at least two departments. At the height of center proliferation at CBS (in 2009), centers numbered more than fourty, most of which had emerged in a bottom-up way over the previous decade. ${ }^{20}$

\footnotetext{
${ }^{18}$ Conversation, 14. June 2009. In this connection, it is important to appreciate Junge-Jensen's background as an organizational scholar and an admirer of March's work, notably March's work on intra-organizational evolutionary processes (e.g., March, 1991). It is also significant that Junge-Jensen is explicit that he derived much inspiration from Burton Clark's (1998) thinking on "entrepreneurial universities."

19 In 2008, CBS initiated a "world class research environment" (WCRE) initiative that would provide additional funding to the best, and supposedly world class, research environments at CBS. More than thirty proposals were submitted from various CBS research environments, leading to six such environments being awarded the WCRE status. The explicit motivation behind this procedure was that CBS top-management realized that they were unable to identify the strongest research environments.

${ }^{20}$ As an example of a successfulendeavor that emerged in this manner, see Foss (2007) on the Center (now Department) for Strategic Management and Globalization (SMG).
} 
Strategy as rules of thumb. Strategy implementation is a well-known challenge in the strategic management process. Thus, middle-management may resist strategies that challenge their positions and influence (Guth and MacMillan, 1986). Or, a strategy may be too complex, largely a ceremonial exercise, or simply divorced from the organization that it is supposed to serve. In all cases, the ability or incentive to implement and pursue the strategy is lacking (Mintzberg, 1994). A potential solution is to communicate and implement strategy in terms of simple actionable rules (Eisenhardt and Sull, 2001).

In retrospect, a number of simple strategic rules were an integral part of the guided evolution approach of CBS. The basic approach could be seen as a set of simple rules, such as, "Any senior faculty member can assemble a group of colleagues and put together a proposal for a center (with mission, timeplan, and budget"; "CBS top-management will consider any such proposal on an ad hoc basis"; "Well-argued proposals will stand a high chance of getting approval"; etc. A related example is what became known as "Finn's Genius Rule", which captured a basic recruitment strategy that has had a major influence on the development of CBS. In a folksy interpretation - to our knowledge it was never codified anywhere-the Genius Rule says: There should be no genius out there in the real world that would like to join CBS that does not get an offer to join the CBS. While this recruitment policy is in itself exemplary of the willingness of CBS to adopt an experimental approach ("geniuses" may be found in diverse disciplines and contexts), as long as the notion of a genius is undefined, the policy in actuality offers much discretion to both top management and pro-active researchers and middle managers to hire whoever they want. Essentially, it provides no guidance for the evolution of scientific areas because the genius rule was not linked to any fields or disciplines.

\section{A Model for University Research Management?}


The argument so far has been that CBS arrived at a distinct "guided evolution" model for organizing its research strategy processes. While this is a model that naturally thrives in a loosely coupled organization, in the case of CBS the guided evolution model is consistent with the history of CBS and its strong emphasis on bottom-up initiative. Although universities because of their loosely coupled nature are likely to inherently manifest aspects of a guided evolution approach, no university has to our knowledge ever adopted a similarly radical model for research organization and strategy. This may partly be a matter of historical legacy. Other universities with a different past, with more of an emphasis on top-down management, may have difficulties adopting a guided evolution model. Moreover, key to the effective functioning of the model was the fact that the particular political circumstance that Finn Junge-Jensen succeeded in securing rather large funds for centrally sponsoring local initiatives. Less politically strong university leaders may not be capable of doing something similar. Finally, a guided evolution approach comes with inbuilt managerial and leadership challenges. In the following we theorize these challenges.

\section{DISCUSSION: CHALLENGES OF GUIDING ORGANIZATIONAL EVOLUTION}

The potential benefits of variety creating approaches, such as guided evolution, are rather wellunderstood in the literature (e.g., March, 1991, 1994; Burgelman, 1994; Ghoshal and Løvås, 2000; Burgelman and Grove, 2007); in particular, such approaches further adaptation to changing environments. However, their drawbacks and managerial challenges are less well-understood. In the following we derive insight into the challenges of guiding organizational evolution, based on the CBS experience. While the reasoning in the following primarily seeks to distill insight from the CBS case that applies to universities, the reasoning may also partially apply to those non-university organizations that share important similarities with universities (such as highly knowledgeintensive, project-based firms with strong disciplinary representations).

\section{Bottom-Up Initiative and Hollowing Out the Core}


In a highly pertinent discussion, Burgelman and Grove (2007: 974) proffered that the "most important contribution top management can make is to appropriately balance induced and autonomous strategy processes to meet the challenges of different strategic dynamics situations." They specifically argue that in stable external environments, there should be a predominance of strategy induced by top-management so as to exploit core business opportunities; yet, topmanagement should allow some autonomous initiatives from below to explore new business opportunities. Given exogenous external change, the induced strategy process essentially serves to retreat in an orderly fashion from previous core business, and the autonomous initiatives facilitate the development of new business opportunities. However, if changes are endogenous (i.e., can be influenced by the focal organization), an induced strategy process makes it possible to exploit new business opportunities while the autonomous initiatives should be played down (but not eliminated) in order to continuously explore new business opportunities.

Seen through the lens of Burgelman and Grove, the strong emphasis at CBS on bottom-up, "autonomous" strategic initiatives best fit organizations that exist in external environments with largely exogenous change. However, CBS is the main player (close to a monopolist) on its (Danish) market for tertiary management education, and the environment may be characterized as largely stable with predictable growth in the student population, and at best minor competitive threats from new entrants, substitutes, or internal rivals. In a stable environment, relying heavily on explorative autonomous strategic initiatives runs the risk of hollowing out core business areas as resources are poured into experimenting with new, potentially more peripheral areas. If top-management's key responsibility is to create the institutional setting for a guided evolution approach, and select among bottom-up strategic initiatives, there is no guarantee that this will strengthen traditional business areas. In a university context, academic entrepreneurs will have strong incentives to carve out new research niches and to explore cross-disciplinary research themes to differentiate their own research 
and position themselves internally and in the relevant research communities. This implies the following proposition:

Proposition 1: In a stable external environment, a guided evolution strategy is associated with hollowing out the core of the organization in the sense that relatively less will be invested in traditional core areas.

In a university, a guided evolution approach can lead to fragmentation in the sense that faculty share less common ground in terms of fundamental insights and ideas. More narrowly, a business school may experience decreasing representation of core ('traditional') management fields (e.g., human resource management, organizational theory and behavior, strategic management, and leadership). This is not to say that the challenge captured by $\mathrm{P} 1$ cannot be addressed. The potential hollowing out that a guided evolution approach may bring justifies systematic research assessment exercises carried out by impartial evaluators so as to help maintain the right balance between core research areas and novel, more exploratory ones.

\section{Type I and Type Mistakes}

The purpose of the guided evolution approach is to stimulate local, explorative efforts that can utilize local knowledge with respect to new developments in research (and in the teaching dimension), while strengthening incentives by empowering individual academics, and easing the leadership burden of top-management. However, the evolutionary processes produced by new variation is still in need of guidance. Thus, top-management provides initial screening of proposals and subsequent evaluation of project performance. Sah and Stiglitz (1985) argue that the organization of such evaluation activities in an organization has a systematic bearing on the incidence of type I and II errors, that is, the organization mistakenly reject a good project and mistakenly accept a bad project. Increasing the ability (i.e., reducing bounds on rationality) of individual evaluators reduce the incidence of type I and II errors. Given the importance of the top 
management team as a central evaluating agency in the guided evolution model, this model would seem to call for university top-managers who are well-versed in research and are not "mere administrators" (cf. Goodall, 2009).

Sah and Stiglitz further argue that organizations can be ordered on a continuum from "polyarchies" to "hierarchies". In a polyarchy a project is only rejected if all organizational units reject it; in a hierarchy a project is only accepted if all units accept the project. Thus, organizational structures are literally structures of evaluation. In a sense, the polyarchy provides few opportunities for project rejection, while the hierarchy provides many. It is intuitive that polyarchies will (therefore) accept more projects (but also more bad projects) than hierarchies. ${ }^{21}$ The guided evolution approach places the evaluating function (initial screening of proposals and subsequent evaluation of projects) directly in the hands of top-management, bypassing hierarchical layers (e.g., department heads) between the proposer and top-management. As such it resembles a polyarchy. This suggests the following proposition:

Proposition 2: A guided evolution approach to strategy is associated with more project acceptance than a more hierarchical or top-down approach, but also leads to the acceptance of projects that ultimately may be of less value for the organization.

In the context of the CBS experience, the guided evolution approach led to a proliferation of research centers, as mentioned; however, at the time of writing, most of these centers have, perhaps tellingly, been closed. The broader import of $\mathrm{P} 2$ is that it may make sense to combine with internal and external evaluation of proposals from the lower echelons of the organizations. A system with only internal evaluation risks overburdening the central decision-maker in terms of her understanding of the content of proposals; this calls for external evaluation. However, internal evaluation may be important to establish legitimacy.

\footnotetext{
${ }^{21}$ Polyarchies and hierarchies are obviously extreme ideal types. However, the same logic applies to the broad spectrum of hybrid designs that exist in between these two extreme types (Christensen \& Knudsen, 2010).
} 


\section{Influence Activities and Decision-making Biases}

Milgrom and Roberts (1992) suggest that while hierarchical authority comes with many benefits (e.g., low-cost coordination of interdependent decisions), it is also associated with distinc costs. Thus, the authority possessed by top-management implies the right to intervene in an organization. Such intervention may be associated with distinct benefits for those that are subject to the intervention. Accordingly, the latter have an incentive to engage in costly "influence activities" that make top-management intervene in a way that is favorable to them. The relevant (influence) costs are not only the resources spent on influencing top-management, but also the costs stemming from errorneous decisions (i.e., type I and type II errors) made by biased top-management. A traditional bureaucratic structure may be associated with information-processing costs; however, it saves on influence because it makes it difficult for members of lower echelons to get access to the ultimate holders of authority, namely top-management.

The hallmark of the guided evolution approach (as practised by CBS) is that decision-making authority with respect to project approval is vested in top-management and that "anyone" (effectively, all senior faculty) can propose projects. In other words, there is little hierarchical distance between those who propose projects and the decision-maker who decides on the fate of projects. $\mathrm{n}$ organizations in which initiative from lower levels is promoted, there is a danger that many resources will be spent on establishing relations with top decision makers in order to improve the probability of acceptance of one's projects. Such rent-seeking activities bias evaluation procedures in undesirable directions and lead to a misallocation of resources. This suggests the following proposition:

Proposition 3: A guided evolution approach to strategy is associated with more influence costs than a more hierarchical or top-down approach.

\section{CONCLUSIONS}


There have been occasional hints that university governance, that is, the allocation of rights across a university to use its resources, interact with the university strategies (Clark, 1998; Jarzabkowski, 2003; Jarzabkowski and Wilson, 2002). However, there is little systematic and cumulative knowledge concerning how this traditional research themes of "strategy and structure" plays out in the context of universities. To throw light over this, we examined, the strategy processes at the CBS from 1987 to 2009 , and identified a distinct mode of approach university strategy, namely the guided evolution approach. We built from the Weickian premise (Weick, 1976) that universities are loosely coupled systems and as such represent specific strategic challenges. Our argument has been that CBS in the period we studied systematized and amplified the beneficial consequences of loosely coupled system by adopting a guided evolution model to strategic management. However, CBS almost certainly also suffered many of those costs that predictably arise in such systems (and which we captured in the above propositions). There are indications that this approach to strategy making is one of the key factors behind the relative success of CBS during the last two decades (e.g., in terms of continuously increasing student intake and moving to the top of the European research rankings), although space has precluded dealing with this in detail.

Overall, the new leadership at the School since Finn Junge-Jensen resigned in 2009 (i.e., Presidents Johan Roos (2009-2011), Per Holten Andersen (2011-2019) and Nicolai MalchowMøller (2019-)) has changed the guided evolution model towards a tighter structure with less room for bottom-up initiative. ${ }^{22}$ In particular, the many independent activities had led to an increasingly complex model that was hard to manage. Strongly reducing the number of research centers (and even reducing the number of departments) has been a means to create a more transparent organization, as has a greater degree of formalization and implementation of standard operating procedures.

\footnotetext{
${ }^{22}$ Relatedly, Foss (2003) describes how a guided evolution approach worked out in a private company (Oticon), unleashed innovation, but also led to many organizational costs. To reduce costs and keep the benefits of guided evolution, management adopted a more hierarchical organizational structure.
} 
The reasoning in this paper is mainly based on a single university case. This obviously dramatically limit the potential generalizability of our findings. However, we potentially add detail to the guided evolution approach by highlighting the incidence of Type I and Type II errors, the potential role of influence costs and so on. As such our single-organization case study has helped us to develop potentially falsifiable new insight in knowledge-intensive, loosely coupled organizations that pursue a guided evolution approach. These organizations may include (some) universities but also more traditional for-profit organizations, such as (some) professional services firms, consultancies, as well as companies that seek to stimulate recovery or transformation by stimulating bottom-up initiative.

\section{REFERENCES}

Aghion, P., Dewatripont, M., Hoxby, M. M., Mas-Colell, A. \& Sapir, A. (2009). The Governance and Performance of Research Universities: Evidence from Europe and the U.S. NBER Working Paper Series, Vol. w14851. Available at SSRN: http://ssrn.com/abstract=1376154

Balslev, L. (1994). Handelshøjskolens Strategikonference. mimeo, (Jnr. 052-1), CBS (7. Sep.1994).

Bansal, P. W.K. Smith, E. Vaara. (2018). New Ways of Seeing Through Qualitative Research. Academy if Management Journal, 62: 1189-95.

Barney, J. B. (1991). Firm Resources and Sustained Competitive Advantage. Journal of Management, 17, 99-120.

Barzel, Y. (1997). Economic Analysis of Property Rights. Cambridge: Cambridge University Press. Bozeman, B. (2000). Technology Transfer and Public Policy: A Review of Research and Theory. Research Policy, 29, 627-655.

Brown, W. O. (2001). Faculty participation in university governance and the effects on university performance. Journal of Economic Behavior and Organization, 44, 129-143.

Burgelman, R. A. (1994). Fading memories: a process theory of strategic business exit in dynamic environments. Administrative Science Quarterly, 39, 24 - 56. 
Burgelman, R. A. \& Grove, A. S. (2007). Let Chaos Reign, then Rein in Chaos - Repeatedly:

Managing Strategic Dynamics for Corporate Longevity. Strategic Management Journal, 28, 965-979.

Chandler, A. D. (1962). Strategy and Structure. Cambridge: MIT Press.

Clark, B. R. (1983). The Higher Education System: Academic Organization in Cross-National Perspective. Berkeley: University of California Press.

Clark, B. R. (1998). Creating Entrepreneurial Universities. Oxford: Pergamon.

Davies, J. L. (2008). Reflections on the development of the Copenhagen Business School, Denmark. Unpublished mimeo.

Dean of the Economics Faculty (1986). Langsigtet faglig planlægning (Long Run Planning of Research Areas). Report, CBS.

Eisenhardt, K. (1989). Building theories from case-study research. Academy of Management Review, 14, 532-550.

Eisenhardt, K. \& Sull, D. (2001). Strategy as simple rules. Harvard Business Review (January), 107-116.

Etzkowitz, H. (1998). The Norms of Entrepreneurial Science: Cognitive Effects of the New Industry-University Linkages. Research Policy, 27, 823-833.

Etzkowitz, H. (2003). Research Groups as Quasi-firms: The Invention of the Entrepreneurial University. Research Policy, 32, 109-121.

Fama, E. F. \& Jensen, M. C. (1983). Agency problems and residual claims. Journal of Law and Economics, 26, 327-349.

Foss, N. J. (2003). Selective Intervention and Internal Hybrids: Interpreting and Learning from the Rise and Decline of the Oticon Spaghetti Organization. Organization Science, 14, 331-349.

Foss, N. J. (2007). Knowledge governance in a dynamic global context: the Centre for Strategic Management and Globalization at the Copenhagen Business School. European Management Review, 4, 183-191.

Geertz, C. (1973). The interpretation of cultures - selected essays by Clifford Geertz. New York: Basic Books Inc Publishers. 
Gibbons, M., Limoges, C. \& Nowotny, H. (1994). The New Production of Knowledge: The Dynamics of Science and Research in Contemporary Societies. London: Sage.

Gioia, D. A. \& Chittipeddi, K. (1991). Sensemaking and sensegiving in strategic change initiation. Strategic Management Journal, 12, 433-448.

Gioia, D. A. \& Thomas, J. B. (1996). Identity, Image, and Issue Interpretation: Sensemaking during Strategic Change in Academia. Administrative Science Quarterly, 41, 370-403.

Goodall, A. (2009). Socrates in the Boardroom: Why Research Universities Should Be Led by Top Scholars. Princeton: Princeton University Press.

Guth, W. D. \& MacMillan, I. C. (1986). Strategy Implementation versus Middle-Management SelfInterest. Strategic Management Journal, 7, 313-327.

Hall, D. J. \& Saias, M. A. (1980). Strategy follows structure. Strategic Management Journal, 1, 149-163.

Handelshøjskolen i København. (1990). Oplæg til drøftelse af strategiplan for Handelshøjskolen i København. mimeo.

Handelshøjskolen i København. (1995). Handelshøjskolens strategiske udvikling. mimeo.

Hayek, F. A. von. (1945). The use of knowledge in society. In Hayek, F.A. von. (Ed.) Individualism and the Economic Order (pp. 77-91). Chicago: University of Chicago Press.

Hermalin, B. E. (1998). Toward an Economic Theory of Leadership: Leading by Example. American Economic Review, 88, 1188-1206.

Huy, Q.N., K. Corley, \& Kraatz, M.S. (2014). From Support to Mutiny: Shifting Legitimacy Judgments and Emotional Reactions Impacting the Implementation of Radical Change, Academy of Management Journal, 57: 1650-1680.

Jacobsen, K. \& Sørensen, A.R. (2017). CBS 100 Years. Copenhagen: Gads Forlag.

Jarzabkowski, P. (2002). Centralised or decentralized? Strategic Implications of Resource Allocation Models. Higher Education Quarterly, 56, 5-32.

Jarzabkowski, P. (2003). Strategic practices: An activity theory perspective on continuity and change. Journal of Management Studies, 40, 23-55.

Jarzabkowski, P. \& Wilson, D. C. (2002). Top teams and strategy in a UK university. Journal of Management Studies, 39, 357-383. 
Jensen, M. C. \& Meckling, W. H. (1992). Specific and general knowledge, and organization structure. In: L. Werin \& H. Wijkander (Ed.), Contract economics. Oxford: Basil Blackwell.

Junge-Jensen, F. (1993). Oplæg vedrørende Handelshøjskolens strategiske udvikling. mimeo dated 27 September 1993 (Jnr. 052-1), CBS.

Junge-Jensen, F. (1995). Perspektiver for Handelshøjskolens strategiske udvikling. mimeo dated 14 August 1995 (Jnr 052-1), CBS.

Junge-Jensen, F. (2006). Strategy 2010. mimeo dated 3 January 2006, CBS.

Junge-Jensen, F. (2008). Strategy for CBS - adopted by the Board of Directors on 19 December 2007; Revised by the Board of Directors on 3 December 2008. mimeo dated 22 December 2008, CBS.

Lam, A. (2007). Knowledge Networks and Careers: Academic Scientists in Industry-University Links. Journal of Management Studies, 44, 993-1016.

Lange, O. (1992). Kampen for en højere laereanstalt: En mosaik omkring Handelshøjskolen 191792. København: Handelshøjskolens Forlag.

Langley, A. 1999. Strategies for Theorizing from Process Data, Academy of Management Review, 24: 691-710.

Løvas, B. \& Ghoshal, S. (2000). Strategy as guided evolution. Strategic Management Journal, 21, 875-891.

Maassen, P. (2000). The Changing Roles of Stakeholders in Dutch University Governance. European Journal of Education, 35, 449-464.

McConnell, T. R. \& Mortimer, K. P. (1971). The Faculty in University Governance. University of California, Berkeley: Center for Research and Development in Higher Education.

March, J. G. (1991). Exploration and exploitation in organizational learning. Organization Science, 2(1), 71-87.

March, J. G. (1994). The evolution of evolution. In Baum, J. A. C. \& Singh, J. V. Evolutionary Dynamics of Organizations. Oxford: Oxford University Press.

Milgrom, P. \& Roberts, J. (1992). Economics, Organization, and Management. Englewood Cliffs: Prentice-Hall. 
Mintzberg, H. (1994). The rise and fall of strategic planning: Reconceiving roles for planning, plans, planners. New York and Toronto: Free Press.

Mintzberg, H., Lampel, J., Quinn, J. B. \& Ghoshal, S. (2003). The strategy process: concepts, contexts, cases. Harlow: Pearson.

Mintzberg, H. \& Waters, J. A. (1985). Of Strategies, Deliberate and Emergent. Strategic Management Journal, 6, 257-272

Orton, J. D. \& Weick, K. E. (1990). Loosely Coupled Systems: A Reconceptualization. Academy of Management Review, 15, 203-223.

Pettigrew, A. M. (1992). Special Issue: Fundamental Themes in Strategy Process Research. Strategic Management Journal, 13, 5-16.

Rothaermel, F. T., Agung, S. D. \& Jiang, L. (2007). University Entrepreneurship: A Taxonomy of the Literature. Industrial and Corporate Change, 16, 691-791.

Sah, R. \& Stiglitz, J. (1985). Human Fallibility and Economic Organization. American Economic Review, 75(2), 292-297.

Shattock, M. (2002). Re-Balancing Modern Concepts of University Governance. Higher Education Quarterly, 56, 235-244.

Shattock, M. 2003. Managing Successful Universities. Berkshire: Open University Press.

Siegel, D. S., Wright, M. \& Lockett, A. (2007). The Rise of Entrepreneurial Activities at Universities: Organizational and Societal Implications. Industrial and Corporate Change, 16 (4), 489-504.

Sporn, B. (1999). Adaptive University Structures. London: Jessica Kingsley Publishers.

Stolt, P. (1993). Status for Handelshøjskolens strategiske udvikling. mimeo (Jnr. 052-1), CBS.

Styhre, A. \& Lind, F. (2009). The Softening Bureaucracy: Accomodating New Research Opportunities in the Entrepreneurial University. Scandinavian Journal of Management (forthcoming).

Strategiudvalget (1989). Strategiudvalgets Rapport - Tankerfra en Task Force, CBS.

Temple, P. \& Whitchurch, C. eds. (1989). Strategic Choice: Corporate Strategies for Change in Higher Education. Reading: CUA. 
Thompson, J. D. (1967). Organizations in Action. New York: McGraw-Hill.

Vibæk, J. \& Kobbernagel, J. (1980). Foreningen til Unge Handelsmands Uddannelse, 1880-1980. Copenhagen: FUHU.

Weick, K. (1976). Educational Organizations as Loosely Coupled Systems. Administrative Science Quarterly, 21, 1-19.

Weick, K. (2007). The generative properties of richness. Academy of Management Journal, 50, 1419.

Whitley, R. J. (2006). Project-based Firms: New Organizational Form or Variations on a Theme? Industrial and Corporate Change, 15, 77-99.

Wooldridge, B. and Floyd, S. W. (1990). The Strategy Process, Middle Management Involvement, and Organizational Performance. Strategic Management Journal, 11, 231-24.

Yin, R. K. (2003). Case study research: design and methods. 3 ed. Thousand Oaks: Sage Publications.

b, R., Wegner, G. F. \& Massy, W. F. (2005). Remaking the American University: Market-Smart and Mission-Centered. Rutgers University Press. 
